\title{
Extra-Mediterranean refugia: The rule and not the exception?
}

Thomas Schmitt $^{1 *}$ and Zoltán Varga ${ }^{2}$

\begin{abstract}
Some decades ago, biogeographers distinguished three major faunal types of high importance for Europe: (i) Mediterranean elements with exclusive glacial survival in the Mediterranean refugia, (ii) Siberian elements with glacial refugia in the eastern Palearctic and only postglacial expansion to Europe and (iii) arctic and/or alpine elements with large zonal distributions in the periglacial areas and postglacial retreat to the North and/or into the high mountain systems. Genetic analyses have unravelled numerous additional refugia both of continental and Mediterranean species, thus strongly modifying the biogeographical view of Europe. This modified notion is particularly true for the so-called Siberian species, which in many cases have not immigrated into Europe during the postglacial period, but most likely have survived the last, or even several glacial phases, in extra-Mediterranean refugia in some climatically favourable but geographically limited areas of southern Central and Eastern Europe. Recently, genetic analyses revealed that typical Mediterranean species have also survived the Last Glacial Maximum in cryptic northern refugia (e.g. in the Carpathians or even north of the Alps) in addition to their Mediterranean refuge areas.
\end{abstract}

Keywords: Phylogeography, Refugia, Faunal types, Last Glacial Maximum (LGM), Postglacial, Range expansions, Range shifts, Mediterranean, Continental, Siberian

\section{Introduction}

The biogeography of the western Palearctic is quite complex and therefore a fascinating and challenging research subject [1-8]. Scientists, even about 50 years ago, distinguished three major faunal components in Europe (Mediterranean, Siberian, arctic and/or alpine), but the interpretation of the underlying biogeographical processes behind these faunal elements has considerably changed since then, e.g. [8-13]. Furthermore, the understanding of climatic and other environmental conditions during glaciations has substantially deepened, e.g. [14-19].

By the time of de Lattin [4], the existence of Mediterranean faunal elements was largely acknowledged (e.g. the "holothermic" faunal elements of Rebel [20]). These elements were thought to have exclusively survived the ice ages in the Mediterranean region, which was divided into nine sub-centres [21] composed of several core areas (German: Arealkerne [2]). Depending on the postglacial expansion out of these refugia and differentiation

\footnotetext{
* Correspondence: thsh@uni-trier.de

'Biogeography, Trier University, D - 54 286, Trier, Germany

Full list of author information is available at the end of the article
}

centres, two basic types were distinguished: (i) stationary elements which did not essentially enlarge their distributions northwards during the postglacial period and (ii) expansive elements largely expanding their ranges beyond their Mediterranean refuge areas, frequently as far north as southern Scandinavia and often showing peripherally isolated populations (subspecies) at the northern boundary of their range e.g. [4] (Figure 1a).

Furthermore, the existence of large ice age distributions in the zonal periglacial belt was suggested for the species with arctic, alpine or arctic-alpine distributions followed by postglacial retreat to high mountain areas in the South and/or the high latitudes in the North. Retreat into both directions was interpreted as the reason for the arctic-alpine disjunctions today [22,23]. However, local endemics e.g. in the Alps were interpreted (at least partly) as in situ survival e.g. at nunataks [23] and/or in some marginal areas of the Alps ("massifs de refuge", [24]) and other southern European high mountain systems $[25,26]$. Thus, the more widespread species in this group were interpreted, following the old monoglacial ideas of Scharff [27], as the only species surviving north
( Biomed Central

(C) 2012 Schmitt and Varga; licensee BioMed Central Ltd. This is an Open Access article distributed under the terms of the Creative Commons Attribution License (http://creativecommons.org/licenses/by/2.0), which permits unrestricted use, distribution, and reproduction in any medium, provided the original work is properly cited. 
a)

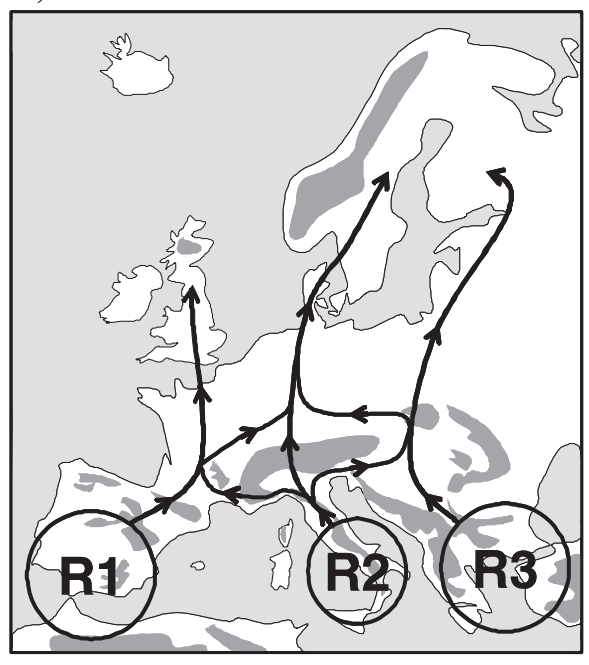

c) b)

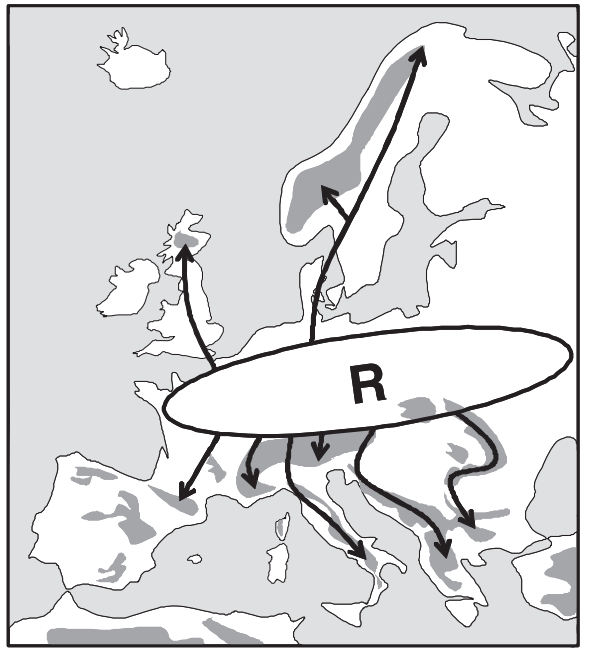

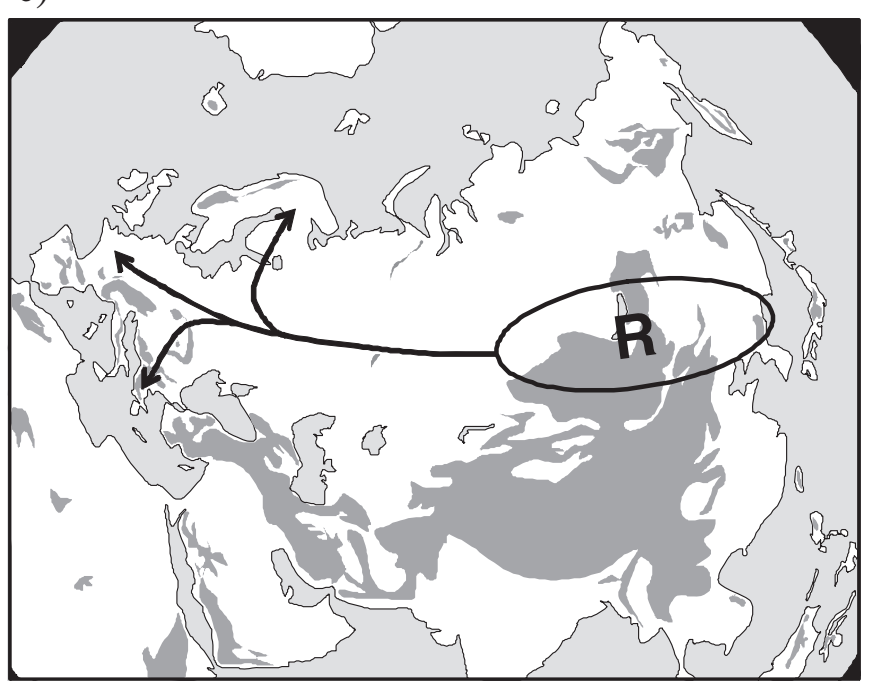

Figure 1 The interpretation of glacial refugia (indicated by "R") and postglacial range changes (indicated by arrows) of the three most important biogeographical elements of Europe (a: Mediterranean, b: arctic/alpine, c: Siberian/Manchurian) as suggested by de Lattin [4], simplified.

of the mountain chains of the Pyrenees, Alps and Carpathians (Figure 1b).

The third biogeographical unit, the large group of species with continental distributions (i.e. missing or rather fragmented in the Mediterranean parts of Europe and absent in the vicinity of the Atlantic) was interpreted as completely missing in Europe during the ice ages, but surviving in the eastern Palearctic in Siberian and/or Manchurian refugia [28]. A postglacial and thus very rapid colonisation of these species throughout Asia to Europe was postulated (Figure 1c) with a typical "line of packing" (i.e. the accumulation of distribution borders; German: Stauungslinie) at the margin of the Mediterranean area (Figure 2). However, this point of view was strongly questioned since the 1960-70ies because this "line of packing" was recognised as an accumulation area of peripheral subspecies of continental species and was also re-considered and interpreted as possible survival areas of such species in some areas of south-central and south-eastern Europe (Figure 2; [25,29-33]). Since then, evidence has accumulated for various extra-Mediterranean refugia in Europe, e.g. [8,9,11-13,34-38].

Over the past two decades genetic analyses of many animal and plant species, representing different biogeographical groups, have strongly enhanced our understanding of the highly complex biogeographical patterns and processes within the western Palearctic [5-8,10,4044]. Therefore, we review the changing view with respect to extra-Mediterranean refugia with a special focus on the geographic location of these refugia, their mostly 


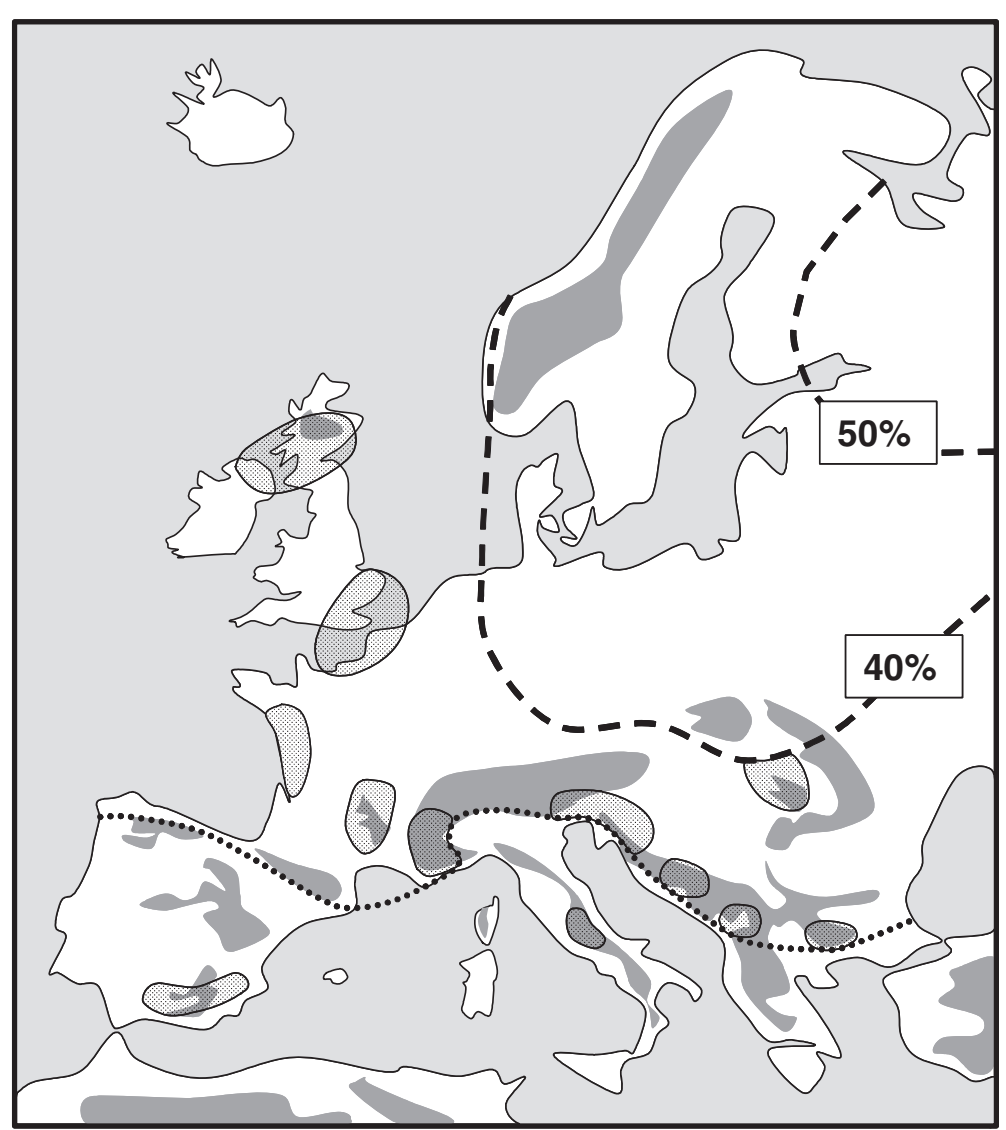

Figure 2 European accumulation zones of marginal subspecies of species showing the continental distribution type (shaded areas). Most of these areas were later discovered as being important as extra-Mediterranean centres of glacial survival of thermophilic species. The southern limits of some of these zones coincide with the line of packing of the "Siberian" faunal type in Europe (sensu de Lattin [4]; dotted line), The representation of "Siberian" species in the local faunal lists is given as broken lines with indication of their respective percentages. Redrawn after de Lattin [4] and Varga [39].

limited spatial extent and often cryptic natures. As recent reviews already address these extra-Mediterranean refugia in artic/alpine species [10,45-48], we focus in this article on continental and Mediterranean species.

\section{Continental species: less mobile but much more complex and diverse}

The species with typical continental distribution patterns (i.e. not reaching the areas with typical Atlantic and Mediterranean climates, but being widely distributed from continental Europe throughout temperate Asia) were formerly thought to have immigrated to Europe from eastern Asiatic Würm glacial refuge areas (i.e. from the Siberian and the Manchurian core areas) during the postglacial period (Figure 1c) [28]. However, this idea was questioned afterwards on the basis of chorological (i.e. the classical interpretation of distribution patterns) and intraspecific taxonomical analyses (cf. Figure 2). Consequently, survival of such continental species was postulated in Europe outside the classical Mediterranean refuge areas [25,29-33].
One of the best studied examples of these continental species is the woodland ringlet Erebia medusa [49-53]. Allozyme analyses over major parts of the species' European distribution range showed strong differentiation into a variety of different genetic lineages: three in Central and East Europe, one in the southern Alps, four or more in and around the Carpathian Basin and one with remarkable sub-structures in Bulgaria [50,51]. Analyses of the mtDNA locus COI of the samples from Central and East Europe, the southern Alps and the western Carpathian Basin strongly supported the genetic lineages detected with allozyme electrophoreses [53]. These results confirm the idea of a larger number of extra-Mediterranean Würm ice age refuge areas in Europe and not postglacial immigration to Europe out of Asiatic core areas. These data strongly support such refugia having been localised (i) west of the Alps, (ii) south of the Alps, (iii) east/south-east of the Alps, (iv) south of the northern Carpathians, (v) in the eastern Carpathian Basin between the Apuseni Mts. and the eastern Carpathians, (vi) on the southern slopes of the 
southern Carpathians and (vii) in the vicinity of the Bulgarian mountain systems, the latter most probably in a structured distribution possibly with temporal disjunctions during some periods of the last ice age (Figure 3). Most of these refugia are assumed to be geographically small and situated in climatically buffered pockets in the landscape cf. [9]. Although numerous morphological subspecies of $E$. medusa have been described, in some cases even supporting these genetic patterns, the refugia postulated on allozyme patterns are even more numerous and are geographically more informative and concise than the known phenotypically differentiated groups. Also, they cannot be deduced from the actual, more or less continuous, distribution pattern of E. medusa. Therefore, the only adequate possibility to comprehensively asses the complex biogeography and refugial structure of this species is through an analysis of its genetic patterns.

A similar situation was observed in the eastern phylogenetic clade of the clouded apollo Parnassius mnemosyne by an analysis of mtDNA sequences of the COI locus over large parts of eastern and south-eastern Europe [54]. This analysis also supported a larger number of extra-Mediterranean Würm ice age refugia from the lower parts of the northern Carpathians and the eastern Alps forelands throughout the Carpathian Basin to the extra-Mediterranean regions of the Balkan Peninsula (Figure 4). The Carpathian Basin shows the overlap of three main haplotype groups of the eastern lineage of this polytypic species. At least one of them has expanded northwards from the Carpathian region reaching southern Finland.
A complex hierarchical pattern was also observed in the adder Vipera berus, a snake distributed from western Europe throughout Asia as far east as the island of Sakhalin. Ursenbacher et al. [55] showed a strong differentiation into three major genetic lineages of most probably pre-Pleistocene origin with two of these being geographically restricted (northern Italian Alps; western Balkan mountains) and one being fairly widespread from France and the UK to the Pacific. The widespread lineage is further divided into several sub-clades of which all apart from one are confined to some part of Europe. These data suggest that two relict lineages most probably survived long periods of time (maybe even the whole Pleistocene) in extra-Mediterranean regions at the southern Alps margin and in the mountainous regions of the western Balkan Peninsula.

The sub-clades in the widespread lineage persisted during at least the last ice age (and maybe even evolved) in other extra-Mediterranean refugia in France, north of the Alps and in the Carpathian Basin. Northern Europe and Asia were postglacially colonised from the northern and north-eastern most lineages, respectively. The refugial populations in France contracted from their ice age distribution to the northern parts of the country and to the British Isles, as well as to the higher elevations (e.g. Massif Central) in southern France (Figure 5).

The sibling Vipera seoanei, restricted to the mountain ranges of northern Iberia, is even more strongly differentiated from $V$. berus than the lineages within this latter species [55]. The split between these two species probably occurred before the beginning of the glacial-interglacial

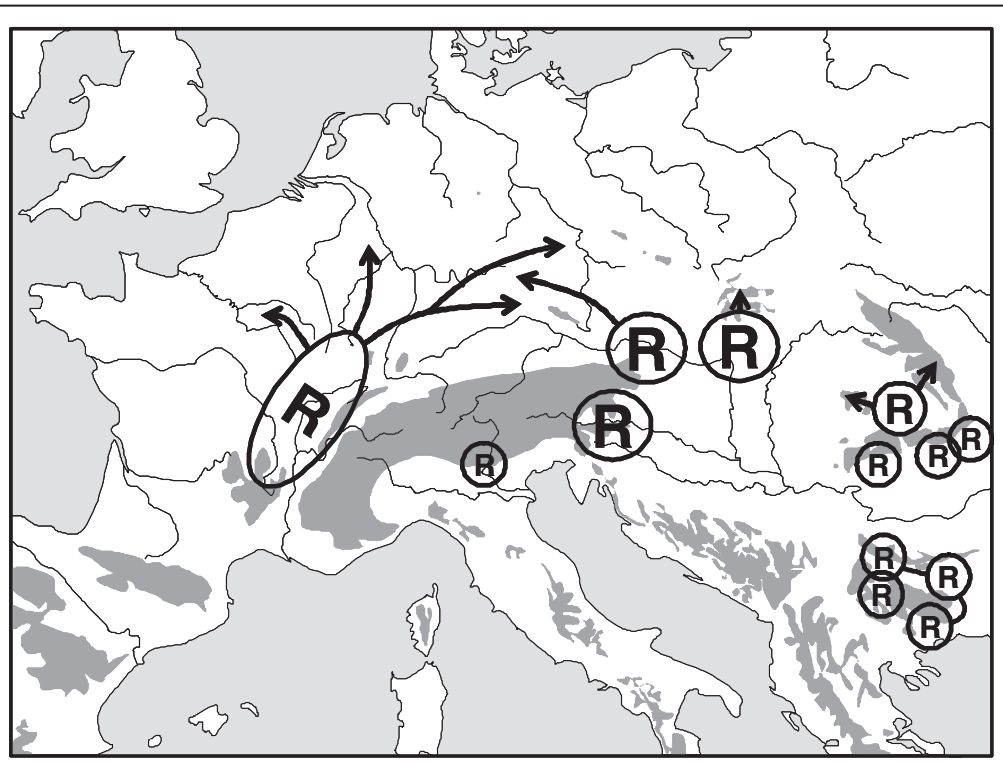

Figure 3 Possible Würm glacial distribution patterns (indicated by "R") of the butterfly Erebia medusa and assumed postglacial range changes (arrows). Overlapping refuge symbols or lines between them indicate possible gene flow between them during the last ice age or even a larger structured refuge area (especially in the case of Bulgaria). Redrawn after Schmitt \& Seitz [51], Schmitt et al. [50] and Hammouti et al. [53]. 


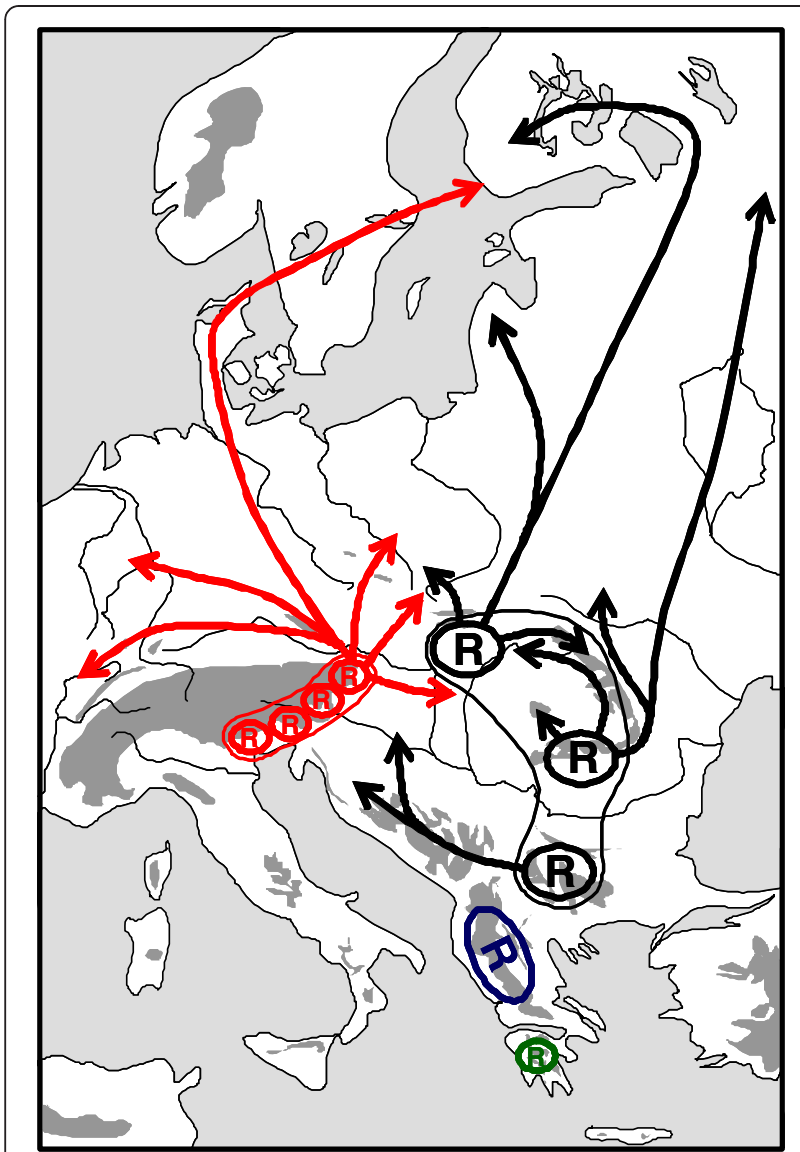

Figure 4 Possible Würm glacial distribution patterns of the butterfly Parnassius mnemosyne, eastern lineage (refuge areas with closely related haplotypes are grouped and in the same colour) and assumed postglacial range changes (arrows) in eastern and south-eastern Europe. Redrawn after Gratton et al. [54].

cycles, with $V$. seoanei most likely having continuously existed over time in the extra-Mediterranean regions of Iberia. It is in this area that the species has two morphologically differentiated subspecies [56], thus indicating two centres of glacial survival.

Furthermore, mtDNA analyses of the snail Arion fuscus support an extra-Mediterranean survival of this species especially in the eastern regions of the Alps, but maybe also in other extra-Mediterranean retreats such as in the area of the Tatras [57]. A strongly differentiated lineage of this species is restricted to the Balkan Peninsula. Whether the respective refugia have to be considered Ponto-Mediterranean or Balkan extra-Mediterranean is in need of further genetic analyses.

The particular importance of a Carpathian refugium as extra-Mediterranean retreat has repeatedly been suggested in several groups of vertebrates, e.g. in the moor frog (Rana arvalis), the agile lizard (Lacerta agilis), the bank vole (Clethrionomys glareolus), the common and the field vole (Microtus arvalis, M. agrestis), the wild boar (Sus scrofa), the roe deer (Capreolus capreolus) and the red deer (Cervus elaphus), and even in the brown bear (Ursus arctos), e.g. [34,35,58-64] (Figure 6). In the lizard Zootoca vivipara, a special mtDNA haplotype restricted to northern Hungary and Austria was found. This ovo-viviparous form shows peculiar karyotypic characters and demonstrates that the ovo-vivipary has independently evolved in the western European and Pannonian (Zootoca vivipara pannonica) populations $[65,66]$.

Surveys of the bank vole (Clethrionomys glareolus) have not only shown the significance of "northern" refugia in the Carpathians, but also in some other areas, e.g., the vicinity of the Alps, southern France, and southern parts of the Ural Mountains (Figure 6b). New fossil and genetic records support the refugial character of the southern Urals in eastern Europe. Recently, a morphometric analysis of bank vole molars has unravelled the existence of a "Ural" morphotype of this species [75].

Although the transitional forest steppic character of the LGM vegetation of the Russian plain already was demonstrated in several palaeo-ecological publications e. g. $[76,77]$, the importance of the refugia in the Urals (Figure 6), also in Kazakhstan and south-western Siberia was only recently shown $[67,78,79]$, and Danukalova et al. [78] pointed out that "the changes of the palaeoenvironment were not so sharp as in the adjacent northwestern territories. Biota of the region has been formed under the influence of the European and Asiatic elements".

For common shrews (Sorex araneus), two major continental refugia have been discovered, one in the southern Urals, from which the re-population of northern Europe started, and a southern Siberian core area which shows a geographic co-incidence with some nemoral species ([67]; further details e.g. in Walter and Straka [80]; Walter and Breckle [81]). These results have been repeatedly confirmed by the karyological and molecular analyses of Wóycik et al. [82], and also perfectly harmonise with the suggested history of postglacial expansion of C. glareolus from a southern continental core area (Urals) to northern Russia [75]. Additionally, in forest bird species, the Caucasus appears to be an area of genetic divergence. Endemic (or nearly so) clusters of haplotypes in the Caucasus have been documented for several species (Carpodacus erythrinus, Motacilla alba, Sitta europaea, Troglodytes troglodytes; reviewed by Zink et al. [83]).

All these examples clearly show that the continental species have had much more refugia and thus, performed much smaller range shifts and expansions than previously thought. Expansion from Siberian core areas into Europe have only been demonstrated in mobile species of boreo-temperate forests such as the great spotted 


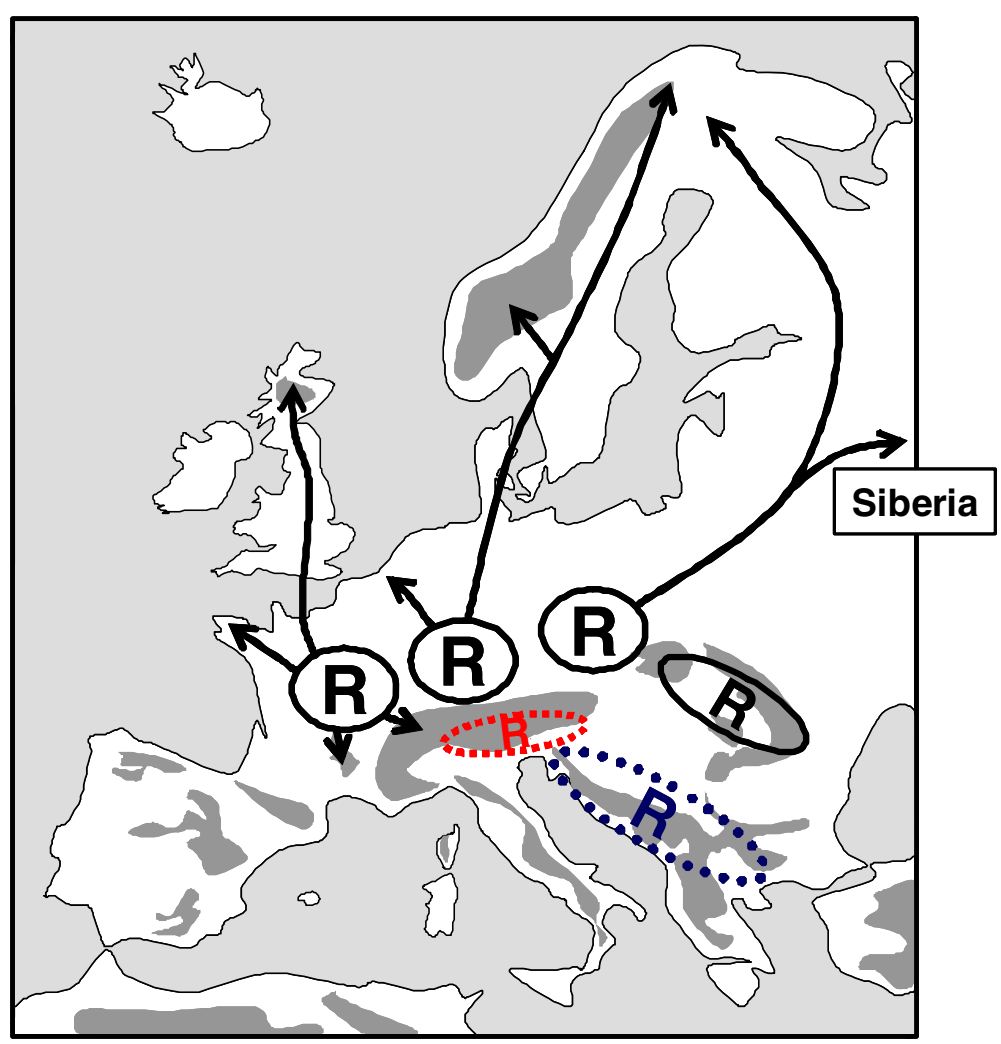

Figure 5 Possible Würm glacial distribution patterns (indicated by "R") of the adder Vipera berus and assumed postglacial range changes (arrows). The three major genetic lineages are indicated by different signatures of the refugia - dotted line, blue: western Balkan lineage; broken line, red: south-eastern Alps line; solid line, black: widespread lineage with different sub-lineages. Redrawn after Ursenbacher et al. [55].

woodpecker (Dendrocopus maior), the boreal warbler (Phylloscopus borealis), the Siberian flying squirrel (Pteromys volans), or the wood lemming (Myopus schisticolor) [84-87]. These species exhibit a higher level of genetic differentiation only at the eastern-southeastern parts of their distributions. Additionally, the dwarf damselfly Nehalennia speciosa, a specialist species of oligotrophic peat bogs, shows a very shallow differentiation all over the Palearctic and most probably expanded from an eastern Asiatic ice age refuge at the beginning of the postglacial period [88]. Some species of boreal forests have had at least two subsequent waves of expansion from the eastern Palaearctic to Europe, from which the representatives of the earlier ones have been preserved in some southern European high mountains as the Pyrenees, the Cantabrian mountains and/or in the Balkans, as e.g. the capercaille $[89,90]$.

For Holarctic boreal forest species, a deeper split has only been shown between the Nearctic and the Palearctic populations (e.g. the birds Picoides tridactylus, Pinicola enucleator, Troglodytes troglodytes), mostly connected with stronger genetic differentiation in the $\mathrm{Ne}$ arctic $[84,91,92]$. Therefore, a direct Siberian invasion to
Europe is rare and can only be supported for some boreal forest species by shallow phylogeographic structures. This pattern might be the strict exception in temperate non-forest species and not one of the paradigms as postulated by de Lattin [28].

In general, these extra-Mediterranean refugia were apparently often located in the vicinity of water donating mountains systems as the glaciated Alps, Carpathians or Balkan mountain systems cf. [51], which may have received more precipitation during the kryoxerotic LGM than the adjacent lowland loess steppe areas. The same idea implicitly appears in some recent papers of Bhagwat and Willis [36], Varga [13] and Stewart et al. [12] supported by habitat preference data of numerous, mostly woody plant and vertebrate species. Furthermore, many of these refugia must have been small and sporadic in their geographic extent $[93,94]$ so that they have been overlooked in the past reconstruction of the glacial faunas mostly based on fossil records. This might explain their cryptic character, which is in clear contrast to their great importance for the re-colonisation of major parts of Europe, a fact that could only be demonstrated by the recent genetic analyses. 


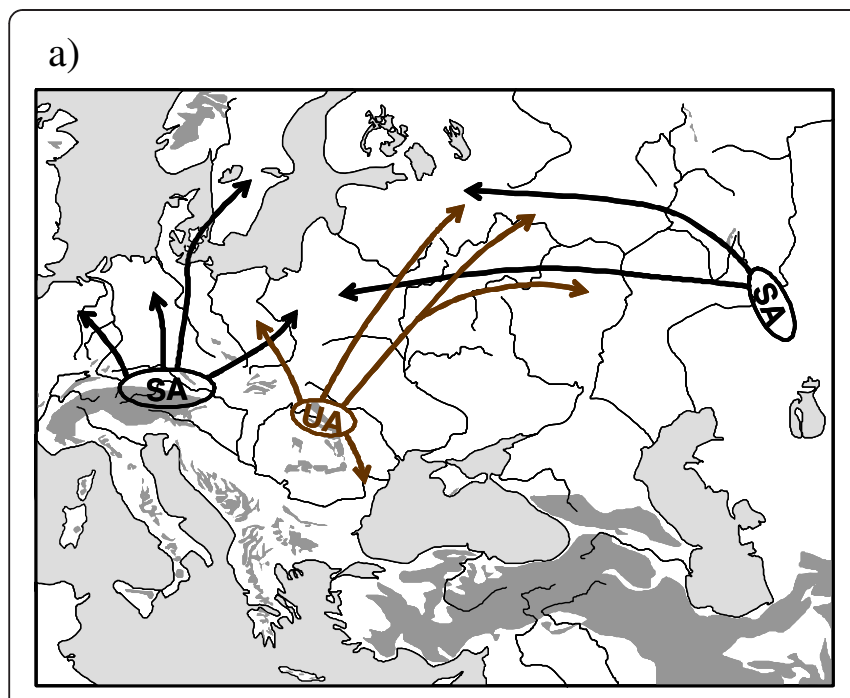

b)

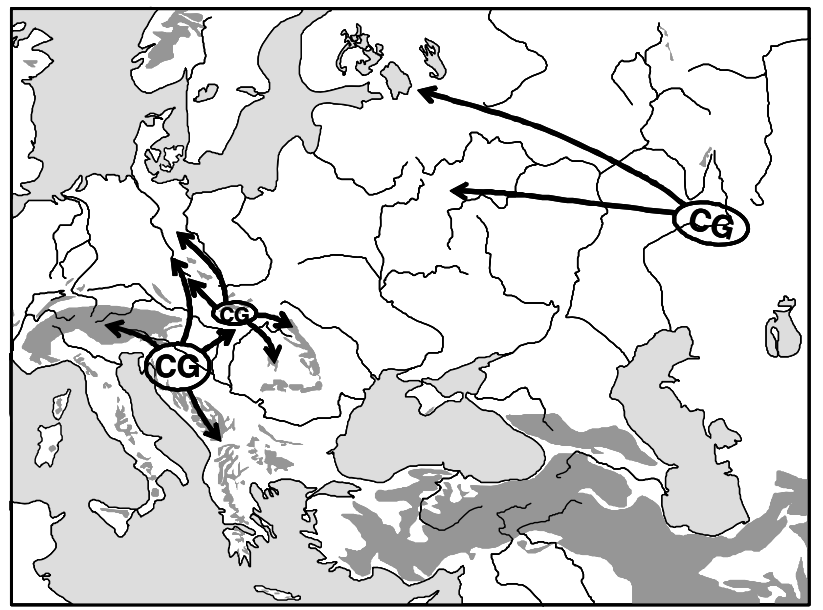

c)

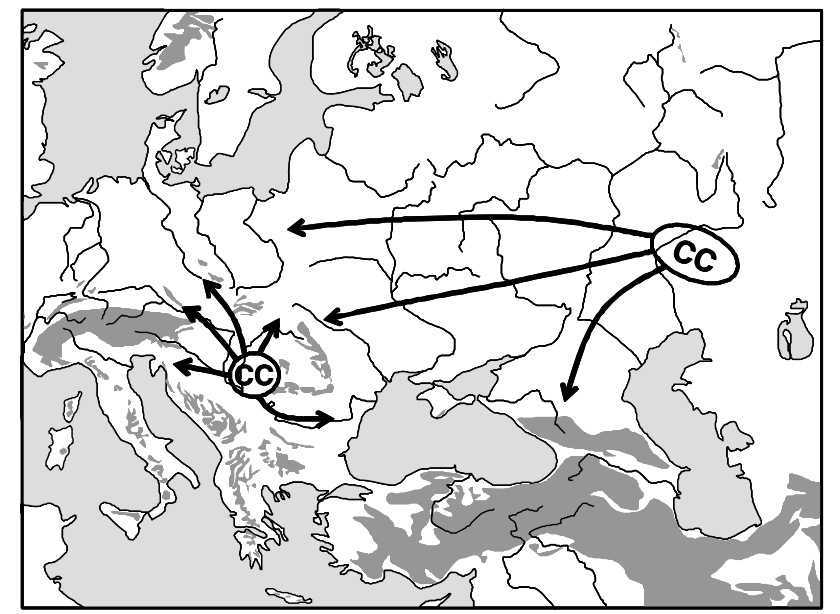

Figure 6 Extra-Mediterranean refugia in eastern Europe and their postglacial expansions of (a) Sorex araneus (SA, black), Ursus arctos (UA, brown), (b) Clethrionomys glareolus (CG) and (c) Cricetus cricetus (CC). Redrawn after Polyakov et al. [67], Hofreiter et al. [68], Hedrick \& Waits [69], Neumann et al. [70], Saarma et al. [62], Valdiosera et al. [71], Ho et al. [72], Krause et al. [73], Korsten et al. [74] and Ledevin et al. [75].

\section{Simultaneous ice age survival in Mediterranean and extra-Mediterranean refugia of temperate species}

De Lattin's paradigm [21] of survival of thermophilic animal and plant species exclusively in Mediterranean Würm refugia remained untouched until quite recently. However, evidence has accumulated that glacial distribution patterns were considerably more intricate than previously thought $[8,38]$, and even additional extraMediterranean ice age refugia are looking more and more likely for some of these Mediterranean taxa [11,12]. The combination of southern and continental refugia became especially evident in the often cited case of the "paradigmatic" brown bear, e.g. [42,62,74,95]. The successful extraction and sequencing of mtDNA from fossil bones has shown the highly complex phylogeographic pattern of this species $[68,69,71-73]$. Thus, the predictions of the "expansion-contraction" (E/C) model were not supported, and consequently the classic glacial refugium model is insufficient to explain the genetic history of European brown bears.

The Pleistocene glacial refugia of the European Bombina toads were located both in the "classical" refugial areas of the Apennines and the Balkans (core areas of $B$. pachypus and subspecies of $B$. variegata; $[96,97])$ as well as more to the North, in the Carpathians and the adjoining lowlands $[98,99]$. Also, strong genetic evidence shows that $B$. variegata survived the LGM in climatically favourable regions in the southern Carpathians. The mtDNA and allozyme data suggest two separate refugia. One clade probably had its refugium in the south-eastern edge of the Carpathians, while the most likely refugium of the other clade was in the area of the southern Carpathians where the highest haplotype diversity was 
detected (Figure 7). However, the deep genetic overall divergence among European Bombina lineages suggests their pre-Pleistocene origin. A similar south-north duplicity was found in the common hamster (Cricetus cricetus) in which a Pannonian and a northern clade have been distinguished [70] with tracks of expansion (i) crossing the "Porta Hungarica" into southern Czech Republic (Moravia), and (ii) north of the Carpathian arc into northern Central Europe (Figure 6c).

Furthermore, Fink et al. [100] found a genetic lineage in the rodent Microtus arvalis, endemic to the region of the Black Forest (south-western Germany). Tougard et al. [63] described two more lineages of this species, which most likely have evolved in extra-Mediterranean refugia of Central and East Europe, including the Carpathian Basin. Consequently, $M$. arvalis survived at least the last ice age in a complex system of extra-Mediterranean and classical Mediterranean core areas. However, we have to assume that the more northern part of the glacial distribution of this vole was, at least transitionally, restricted to geographically small regions with a more buffered climate, thus only some extra-zonal areas in the periglacial tundra and steppe region, although $M$. arvalis in general was a common component of fossil remains of last glacial faunas [101].

The highly important recent work on the phylogeography of the beech, Fagus sylvatica, [102,103] strongly suggest a larger number of additional but geographically restricted extra-Mediterranean Würm glacial refugia for this species, which beforehand had always been considered to be of pure Mediterranean origin cf. [6]. Thus, retreats were demonstrated in Mediterranean southern Italy and in a number of geographically restricted areas in the Balkan Peninsula, of which some even should have been located in the continental extra-Mediterranean part of this peninsula. A similar pattern is true for Iberia where the retreats were most probably located along the northern mountain chains of the Cordillera Cantabrica and thus in the extra-Mediterranean area of this region. Further extra-Mediterranean refugia of the beech are likely in two areas of southern France (with one in the vicinity of the Massif Central), the eastern Alps and, maybe, the Carpathian Basin (Apuseni Mts.) and the northern Carpathians (Figure 8). Furthermore, refugia for some other but more cold-tolerant tree species were frequently proved for the Carpathian region and the Carpathian Basin by classical pollen analyses and macrofossil surveys, e.g. [37,38,104-112].

\section{General discussion and conclusions}

A large number of recent publications have shown the great importance of extra-Mediterranean refugia for temperate species and not only for alpine and arctic taxa. While the latter two groups may have frequently had wide ranges over this cold-continental zonobiome [10], the glacial range contractions of thermophilic temperate species, in most cases, must have led to small (and very small) meso- or microclimatically favourable extra- or intrazonal areas within the extended periglacial belt.

Many species with typical continental distributions might have had glacial distribution patterns with multiple extra-Mediterranean refugia, and were mostly not

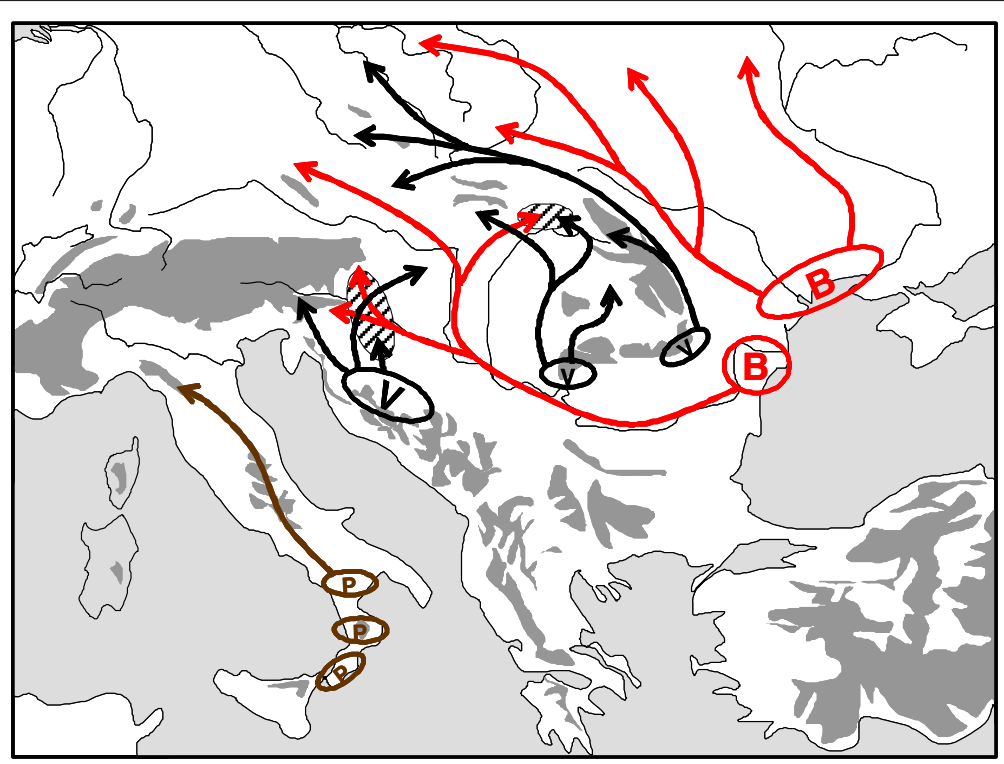

Figure 7 Possible Würm glacial distribution patterns of fire-bellied toads (indicated by "B" (in red) for Bombina bombina, "V" (in black) for B. variegata and "P" (in brown) for B. pachypus) and assumed postglacial range changes (arrows) in Europe. Areas of sympatry of both species are indicated by hatched areas. Redrawn after Szymura et al. [96], Canestrelli et al. [97], Vörös et al. [98] and Hofman et al. [99]. 


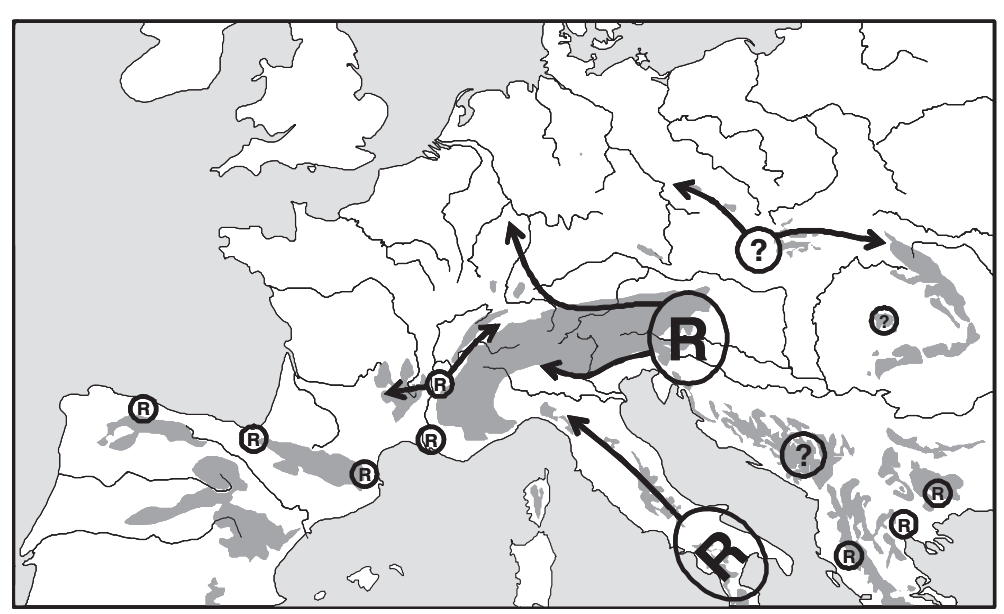

Figure 8 Possible Würm glacial distribution patterns (indicated by "R"; "?" is used in cases of still doubtful refuge areas) of the beech, Fagus sylvatica, and assumed postglacial range changes (arrows). Redrawn after Magri et al. [102] and Magri [103].

restricted to refuge areas in the eastern Palearctic, as often previously thought. However, this is not to say that they were absent from the eastern Palearctic, but these contractions were not the exclusive ones for these species.

Instead, recent research showed that even thermophilic species, which were formerly thought of having been completely restricted to Mediterranean core areas, could in some cases survive in extra-Mediterranean refugia in addition to the typical Mediterranean areas. Such populations in many cases have an even higher genetic diversity and expansive power than populations restricted to the more southern "classical" refugia.

These observations can be explained by two different factors, which might have acted in combination. The southern refugia of temperate species were often surrounded by extended cold-arid steppe areas, e.g. in the central part of the Balkan Peninsula and also in the Carpathian Basin [113]. Furthermore, the populations of the scattered extra-Mediterranean refugial pockets could expand and hybridise among each other during the milder interstadial phases of the Würm and also between the LGM and the younger Dryas period [12]. It means that these extra-Mediterranean refuge populations have survived at the rear edge of the range during the ice ages, with all evolutionary consequences of this situation [114]. These ice age rear edges became the leading edges of the postglacial northwards range expansions, thus strongly impacting the genetic constitution of Central and North Europe in many plant and animal species. In many cases, such populations have been characterised as localised subspecies of extended polytypic continental species, and they are considered as evolutionarily significant units (ESUs) of high conservation priority [95].
For all these reasons, the extra-Mediterranean refugia apparently represent an important biogeographical component of the western Palaearctic, maybe nearly equivalent to the Mediterranean refugia further south.

Through these new findings, we can also answer the question of the article's title: whether extra-Mediterranean refugia are the rule or the exception. In fact, they are a bit of both. Extra-Mediterranean refugia have been a common feature during, at least, the last ice age and thus are paradigmatic. However, they are also represented by many individual patterns of particular biogeographical features so that each case shows at least some uniqueness. The principle of individual responses of the species to climatic oscillations between glacial and interglacial conditions was repeatedly postulated in this context (cf. Stewart et al., [12], but also see Bhagwat \& Willis [36]). During glaciations, ecosystems that exist today had been largely disintegrated and were represented by de novo ecosystems without close connection with the succeeding ones (e.g. the mammoth steppe with tundra, cold steppic and alpine elements). These ecosystems were locally intermingled with small forest refugia (i.e. the pockets of forests of Bhagwat \& Willis, [36]) and also showed non-analogous mammal assemblages $[13,35,77,115]$.

Therefore, no regular North-South shifts took place between glacial and interglacial conditions and vice versa (as implicitly assumed in the biogeographical range paradigms, cf. $[5,6])$. Instead, a new sequence of ecosystems always had to be established, influenced by a combination of precipitation and temperature. The newly evolved macro-biome of a continental cold steppe (that no longer exists) must have had characteristic macroecotones against the (glacially reduced) boreal forests 
and against the continental meadow steppes of temperate latitudes.

Although not existing under the recent climatic conditions, these macro-ecotones can be modelled based on the zonality of the cold-continental conditions of southern Siberia, northern Mongolia or even Yakutia. Here, many floral and faunal elements can be observed together on species-rich meadow steppes of these regions, species assemblages, which are partitioned to different habitats in eastern Europe like dry steppic grasslands, meadow steppes, damp meadows or even salt meadows. The large number of macro-ecotones with their specific species assemblages is the background for the phenomenon of the evolution of so many species specific biogeographies, but hereby also for the paradigmatic patterns, i. e. the regular existence of micro-refugia. However, this is only a special case of the law of uniformity because even today such micro-refugia with peculiar mixtures of faunal and floral elements exist under analogous climatic conditions.

\section{Competing interests}

The authors declare that they have no competing interests.

\section{Author's contributions}

Both authors wrote this article in equal parts. Both authors read and approved the final manuscript.

\begin{abstract}
Author's information
Thomas Schmitt is Professor of Molecular Biogeography at Trier University. His main scientific interests are biogeography (classical and molecular), ecology (classical and molecular), evolutionary biology, conservation biology as well as the taxonomy of butterflies. He also has a special interest in the high mountain systems of the western Palearctic.

Zoltán Varga is Professor emeritus of Zoology at the University of Debrecen. His scientific focus is on biogeography, evolutionary biology, conservation biology and ecology as well as the taxonomy of butterflies and noctuid moths. He is one of the leading experts for the Carpathian Basin, the Balkan Peninsula and the arid zones of Central Asia.
\end{abstract}

\section{Author details}

${ }^{1}$ Biogeography, Trier University, D - 54 286, Trier, Germany. ${ }^{2}$ Dept. Evolutionary Zoology, Faculty of Science and Technology, University of Debrecen, Egyetem-tér 1, Debrecen H-4010, Hungary.

Received: 29 June 2012 Accepted: 28 August 2012

Published: 6 September 2012

\section{References}

1. Reinig W: Die Holarktis. Jena: Fischer; 1937.

2. Reinig W: Chorologische Voraussetzungen für die Analyse von Formenkreisen. In Syllegomena biologica: Festschrift zum 80. Geburtstage von Otto Kleinschmidt. Edited by van Jordans A, Peus F, Kleinschmidt O. Leipzig: Ziemsen; 1950:346-378.

3. De Lattin G: Die Ausbreitungszentren der holarktischen Landtierwelt. In Verhandlungen der Deutschen Zoologischen Gesellschaft vom 21. bis 26. Mai 1956 in Hamburg. Edited by Pflugfelder O. Leipzig: Geest \& Portig; 1957:380-410,

4. De Lattin G: Grundriß der Zoogeographie. Jena: Verlag Gustav Fischer; 1967.

5. Hewitt GM: Some genetic consequences of ice ages, and their role in divergence and speciation. Biol J Linn Soc 1996, 58:247-276.

6. Hewitt GM: Post-glacial re-colonization of European biota. Biol J Linn Soc 1999, 68:87-112.

7. Hewitt GM: The genetic legacy of the Quaternary ice ages. Nature 2000, 405:907-913.
8. Schmitt T: Molecular Biogeography of Europe: Pleistocene cycles and postglacial trends. Front Zool 2007, 4:11.

9. Stewart JR, Lister AM: Cryptic northern refugia and the origins of the modern biota. Trends Ecol Evol 2001, 16:608-613.

10. Schmitt $\mathrm{T}$ : Biogeographical and evolutionary importance of the European high mountain systems. Front Zool 2009, 6:9.

11. Provan J, Bennett KD: Phylogeographic insights into cryptic glacial refugia. Trends Ecol Evol 2008, 23:564-571.

12. Stewart JR, Lister AM, Barnes I, Dalén L: Refugia revisited: individualistic responses of species in space and time. Proc $R$ Soc B 2010, 277:661-671.

13. Varga Z: Extra-Mediterranean refugia, post-glacial vegetation history and area dynamics in Eastern Central Europe. In Relict Species: Phylogeography and Conservation Biology. Edited by Habel JC, Assmann T. Heidelberg: Springer; 2010:57-87.

14. Huybers $P$, Wunsch C: Obliquity pacing of the late Pleistocene glacial terminations. Nature 2005, 434:491-494.

15. Jahn A, Claussen M, Ganopolski A, Brovkin V: Quantifying the effect of vegetation dynamics on the climate of the Last Glacial Maximum. Clim Past Discuss 2005, 1:1-16.

16. Quante M: The Changing Climate: Past, Present, Future. In Relict Species: Phylogeography and Conservation Biology. Edited by Habel JC, Assmann T. Heidelberg: Springer; 2010:9-56.

17. Willis KJ, Bhagwat SA: Questions of importance to the conservation of biological diversity: answers from the past. Clim Past Discuss 2010, 6:759-769.

18. De Bruyn M, Hoelzel R, Carvalho GR, Hofreiter M: Faunal histories from Holocene ancient DNA. Trends Ecol Evol 2011, 26:405-413.

19. Woillez M-N, Kageyama M, Krinner G, de Noblet-Ducoudré N, Viovy N, Mancip M: Impact of $\mathrm{CO}_{2}$ and climate on the Last Glacial Maximum vegetation: results from the ORCHIDEE/IPSL models. Clim Past 2011, 7:557-577.

20. Rebel H: Zur Frage der europäischen Faunenelemente. Annalen Naturhist Mus Wien 1931, 46:49-55.

21. De Lattin G: Beiträge zur Zoogeographie des Mittelmeergebietes. Verh Dt Zool Ges 1949, 42:143-151.

22. Holdhaus K, Lindroth C: Die europäischen Koleopteren mit boreo-alpiner Verbreitung. Annalen Naturhist Mus Wien 1939, 50:123-293.

23. Holdhaus K: Die Spuren der Eiszeit in der Tierwelt Europas. Innsbruck: Universitätsverlag Wagener; 1954.

24. Jeannel R: La genèse des faunes terrestres. Paris: Presses Universitaires de France; 1943.

25. Varga Z: Geographische Isolation und Subspeziation bei den Hochgebirgs-Lepidopteren der Balkanhalbinsel. Acta Entomol Jugoslavica 1975, 11:5-40.

26. Varga Z: Biogeography and Evolution of the oreal Lepidoptera in the Palearctic. Acta Zool Hung 1996, 42:289-330.

27. Scharff RF: The history of the European fauna. London: Walter Scott; 1899.

28. De Lattin G: Die Verbreitung des sibirischen Faunenelements in der Westpaläarktis. Nat Mus 1964, 94:104-125.

29. Varga Z: Taxonomic survey of the SE-European forms of Melitaea phoebe Schiff. (Lep.: Nymphalidae) with description of two new subspecies (in Hungarian with English summary). Acta Biol Debrecina 1967, 5:119-137.

30. Varga Z: Das Prinzip der areal-analytischen Methode in der Zoogeographie und die Faunenelemente-Einteilung der europäischen Tagschmetterlinge (Lep.: Diurna). Acta Biol Debrecina 1977, 14:223-285.

31. Aspöck H, Aspöck U, Rausch H: Polyzentrische Ausbreitung eines "Sibirisch-mediterranen" Faunenelements am Beispiel der Polytypischen Kamelhalsfliege Raphidia ophiopsis L. (Neuroptera, Raphidioptera, Raphidiidae). Zeitschr Arbeitsgem Österr Entomol 1976, 28:89-105.

32. Aspöck H: Die Herkunft der Raphidiopteren des extramediterranen Europa - eine kritische biogeographische Analyse. In Verhandlungen des VII. Leningrad: Internationalen Symposiums über Entomofaunistik in Mitteleuropa, 1977; 1979:14-22.

33. Malicky H: Chorological patterns and biome types of European Trichoptera and other freshwater insects. Archiv Hydrobiol 1983, 96:223-244.

34. Kotlík P, Deffontaine V, Mascheretti S, Zima J, Michaux JR, Searle JB: A northern glacial refugium for bank voles (Clethrionomys glareolus). Proc Natl Acad Sci USA 2006, 103:14860-14864.

35. Sommer RS, Nadachowski A: Glacial refugia of mammals in Europe: evidence from fossil records. Mammal Rev 2006, 36:251-265.

36. Bhagwat SA, Willis KJ: Species persistence in northerly glacial refugia of Europe: a matter of chance or biogeographical traits? J Biogeogr 2008, 35:464-482. 
37. Birks HJB, Willis KJ: Alpines, trees, and refugia in Europe. Plant Ecol Divers 2008, 1:147-160.

38. Svenning J-C, Normand S, Kageyama M: Glacial refugia of temperate trees in Europe: insights from species distribution modelling. J Ecol 2008, 96:1117-1127

39. Varga Z: Extension, isolation, micro-évolution. Acta Biol Debrecina 1971, 8:195-211

40. Hewitt GM: Speciation, hybrid zones and phylogeography — or seeing genes in space and time. Mol Ecol 2001, 10:537-549.

41. Hewitt GM: Genetic consequences of climatic oscillation in the Quaternary. Phil Trans R Soc Lond B 2004, 359:183-195.

42. Taberlet P, Fumagalli L, Wust-Saucy A-G, Cosson J-F: Comparative phylogeography and postglacial colonization routes in Europe. Mol Ecol 1998, 7:453-464

43. Habel JC, Schmitt T, Müller P: The fourth paradigm pattern of post-glacial range expansion of European terrestrial species: the phylogeography of the Marbled White butterfly (Satyrinae, Lepidoptera). J Biogeogr 2005, 32:1489-1497.

44. Randi E: Phylogeography of South European mammals. In Phylogeography of Southern European Refugia. Edited by Weiss S, Ferrand N. Dordrecht: Springer; 2007:101-126.

45. Tribsch A, Schönswetter P: In search for Pleistocene refugia for mountain plants: patterns of endemism and comparative phylogeography confirm palaeo-environmental evidence in the Eastern European Alps. Taxon 2003, 52:477-497.

46. Schönswetter P, Stehlik I, Holderegger R, Tribsch A: Molecular evidence for glacial refugia of mountain plants in the European Alps. Mol Ecol 2005, 14:3547-3555

47. Holderegger R, Thiel-Egenter $\mathrm{C}$ : A discussion of different types of glacial refugia used in mountain biogeography and phylogeography. J Biogeogr 2009, 36:476-480.

48. Schmitt T, Muster C, Schönswetter P: Are disjunct alpine and arctic-alpine animal and plant species in the western Palearctic really "relics of a cold past"? In Relict Species: Phylogeography and Conservation Biology. Edited by Habel JC, Assmann T. Heidelberg: Springer; 2010:239-252.

49. Schmitt T, Varga Z, Seitz A: Forests as dispersal barriers for Erebia medusa (Nymphalidae, Lepidoptera). Basic Appl Ecol 2000, 1:53-59.

50. Schmitt T, Rákosy L, Abadjiev S, Müller P: Multiple differentiation centres of a non-Mediterranean butterfly species in south-eastern Europe. J Biogeogr 2007, 34:939-950.

51. Schmitt T, Seitz A: Intraspecific allozymatic differentiation reveals the glacial refugia and the postglacial expansions of European Erebia medusa (Lepidoptera: Nymphalidae). Biol J Linn Soc 2001, 74:429-458.

52. Schmitt T, Müller P: Limited hybridization along a large contact zone between two genetic lineages of the butterfly Erebia medusa (Satyrinae, Lepidoptera) in Central Europe. J Zool Syst Evol Res 2007, 45:39-46.

53. Hammouti N, Schmitt T, Seitz A, Kosuch J, Veith M: Combining mitochondrial and nuclear evidences: a refined evolutionary history of Erebia medusa (Lepidoptera: Nymphalidae: Satyrinae) in Central Europe based on the CO1 gene. J Zool Syst Evol Res 2010, 48:115-125.

54. Gratton P, Konopinski MK, Sbordoni V: Pleistocene evolutionary history of the Clouded Apollo (Parnassius mnemosyne): genetic signatures of climate cycles and a 'time-dependent' mitochondrial substitution rate. Mol Ecol 2008, 17:4248-4262.

55. Ursenbacher S, Carlsson M, Helfer V, Tegelström H, Fumagalli L: Phylogeography and Pleistocene refugia of the adder (Vipera berus) as inferred from mitochondrial DNA sequence data. Mol Ecol 2006, 15:3425-3437.

56. Martínez Freiría F: Biogeografía y ecología de las víboras ibéricas (Vipera aspis, V. latastei y V. seoanei) en una zona de contacto en el norte peninsular. PhD thesis.: University of Salamanca; 2009.

57. Pinceel J, Jordaens K, Pfenninger M, Backeljau T: Rangewide phylogeography of a terrestrial slug in Europe: evidence for Alpine refugia and rapid colonization after the Pleistocene glaciations. Mol Ecol 2005, 14:1133-1150.

58. Jaarola M, Searle JB: Phylogeography of field voles (Microtus agrestis) in Eurasia inferred from mitochondrial DNA sequences. Mol Ecol 2002, 11:2613-2621.

59. Babik W, Branicki W, Sandera M, Litvinchuk S, Borkin LJ, Irwin JT, Rafinski J: Mitochondrial phylogeography of the moor frog, Rana arvalis. Mol Ecol 2004, 13:1469-1480

60. Deffontaine V, Libois R, Kotlík P, Sommer R, Nieberding C, Paradis E, Searle JB, Michaux JR: Beyond the Mediterranean peninsulas: evidence of Central European glacial refugia for a temperate forest mammal species, the bank vole (Clethrionomys glareolus). Mol Ecol 2005, $14: 1727-1739$

61. Joger U, Fritz U, Guicking D, Kalyabina-Hauf S, Nagy ZT, Wink M: Phylogeography of western Palaearctic reptiles: Spatial and temporal speciation patterns. Zool Anz 2007, 246:293-313.

62. Saarma U, Ho SYW, Pybus OG, Kaljuste M, Tumanov IL, Kojola I, Vorobiev AA, Markov NI, Saveljev AP, Valdmann H, Lyapunova EA, Abramov AV, Männil P, Korsten M, Vulla E, Pazetnov SV, Pazetnov VS, Putchkovskiy SV, Rokov AM: Mitogenetic structure of brown bears (Ursus arctos L.) in north-eastern Europe and a new time frame for the formation of European brown bear lineages. Mol Ecol 2007, 16:401-413.

63. Tougard C, Renvoisé E, Petitjean A, Quéré J-P: New insight into the colonization processes of common voles: inferences from molecular and fossil evidence. PLoS One 2008, 3:e3532.

64. Davison J, Ho SYW, Bray SC, Korsten M, Tammeleht E, Hindrikson M, Østbye K, Østbye E, Lauritzen S-E, Austin J, Cooper A, Saarma U: Late-Quaternary biogeographic scenarios for the brown bear (Ursus arctos), a wild mammal model species. Quat Sci Rev 2011, 30:418-430.

65. Kupriyanova LA, Mayer W, Böhme W: Karyotype diversity of the Eurasian lizard Zootoca vivipara (Jacquin, 1787) from Central Europe and the evolution of viviparity. In Proceedings of the 13th Congress of the Societas Europaea Herpetologica; 2006:67-72

66. Surget-Groba Y, Heulin B, Guillaume C-P, Puky M, Semenov B, Orlova V, Kupriyanova L, Ghira I, Smajda B: Multiple origins of viviparity, or reversal from viviparity to oviparity and the evolution of parity. Biol J Linn Soc 2006, 87:1-11.

67. Polyakov AV, Panov W, Ladygina TY, Bochkarev MN, Rodionova MI, Borodin PM: Chromosomal Evolution of the Common Shrew Sorex araneus L. from the Southern Urals and Siberia in the Postglacial Period. Russ $J$ Genet 2001, 37:351-357.

68. Hofreiter M, Serre D, Rohland N, Rabeder G, Nagel D, Conard N, Münzel S, Pääbo S: Lack of phylogeography in European mammals before the last glaciation. Proc Natl Acad USA 2004, 101:12963-12968.

69. Hedrick P, Waits L: What the ancient DNA tells us? Heredity 2005, 94:463-464

70. Neumann K, Michaux JR, Maak S, Jansman HAH, Kayser A, Mundt G Gattermann R: Genetic spatial structure of European common hamsters (Cricetus cricetus) - a result of repeated range expansion and demographic bottlenecks. Mol Ecol 2005, 14:1473-1483.

71. Valdiosera CE, Garcia N, Anderlung C, Dalen L, Cregut-Bonnoure E, Kahlke RD, Stiller M, Brandström M, Thomas MG, Arsuaga J-L, Götherström A, Barnes I: Staying out in the cold: glacial refugia and mitochondrial DNA phylogeography in ancient European brown bears. Mol Ecol 2007, 16:5140-5148

72. Ho SYW, Saarma U, Barnett R, Haile J, Shapiro B: The effect of inappropriate calibration: three case studies in molecular ecology. PLoS One 2008, 3:e1615.

73. Krause J, Unger T, Noçon A, Malaspinas A-S, Kolokotronis S-O, Stiller M, Soibelzon L, Spriggs H, Dear PH, Briggs A-W, Bray SCE, O'Brien SJ, Rabeder G, Matheus P, Cooper A, Slatkin M, Pääbo S, Hofreiter M: Mitochondrial genomes reveal an explosive radiation of extinct and extant bears near the Miocene-Pliocene boundary. BMC Evol Biol 2008, 8:220.

74. Korsten M, Ho SYW, Davison J, Pähn B, Vulla E, Roht M, Tumanov IL, Kojola I, Andersone-Lilley Z, Ozolins J, Pilot M, Mertzanis Y, Giannakopoulos A, Vorobiev AA, Markov NI, Saveljev AP, Lyapunova EA, Abramov AV, Männil P, Valdmann H, Pazetnov SV, Pazetnov VS, Rokov AM, Saarma U: Sudden expansion of a single brown bear maternal lineage across northern continental Eurasia after the last ice age: a general demographic model for mammals? Mol Ecol 2009, 18:1963-1979.

75. Ledevin R, Michaux JR, Deffontaine V, Henttonen H, Renaud S: Evolutionary history of the bank vole Myodes glareolus: a morphometric perspective. Biol J Linn Soc 2010, 100:681-694.

76. Velichko AA, Catto N, Drenova AN, Klimanova VA, Kremenetskia KV, Nechaeva VP: Climate changes in East Europe and Siberia at the Late glacial-holocene transition. Quat Internat 2002, 91:75-99.

77. Simakova AN: The vegetation of the Russian Plain during the second part of the Late Pleistocene (33-18 ka). Quat Internat 2006, 149:110-114.

78. Danukalova G, Yakovlev A, Kosintcev P, Agadjanian A, Alimbekova L, Eremeev A, Morozova E: Quaternary fauna and flora of the Southern Urals region (Bashkortostan Republic). Quat Internat 2009, 201:13-24.

79. Horsák M, Chytry M, Danihelka J, Kocí M, Kubesova S, Kalososova Z, Otypkova Z, Tichy L: Snail faunas in the Ural forests and their relations to 
vegetation: an analogue of the early Holocene assemblages of Central Europe? J Mollus Stud 2010, 76:1-10.

80. Walter H, Straka H: Arealkunde. Floristisch-historische Geobotanik. Stuttgart: Ulmer; 1970.

81. Walter H, Breckle S-W: Ökologie der Erde. Spezielle Ökologie der Gemäßigten und Arktischen Zonen Euro-Nordasiens. Stuttgart: Fischer; 1986.

82. Wójcik JM, Ratkiewicz M, Searle JB: Evolution of the common shrew Sorex araneus: chromosomal and molecular aspects. Acta Theriol 2002, 47(Suppl. 1):139-167.

83. Zink RM, Drovetski SV, Rohwer S: Selective neutrality of mitochondrial ND2 sequences, phylogeography and species limits in Sitta europaea. Mol Phylogen Evol 2006, 40:679-686.

84. Zink RM, Drovetski SV, Rohwer S: Phylogeographic patterns in the great spotted woodpecker Dendrocopos major across Eurasia. J Avian Biol 2002, 33:175-178.

85. Oshida T, Abramov A, Yanagava H, Masuda R: Phylogeography of the Russian flying squirrel (Pteromys volans): implication of refugia theory in arboreal small mammal of Eurasia. Mol Ecol 2005, 14:1191-1196.

86. Fedorov VB, Goropashnaya AV, Boeskorov GG, Fredga K: Comparative phylogeography and demographic history of the wood lemming (Myopus schisticolor): implications for late Quaternary history of the taiga species in Eurasia. Mol Ecol 2008, 17:598-610.

87. Saitoh T, Alström P, Nishiumi I, Shigeta Y, Williams D, Olsson U, Ueda K: Old divergences in a boreal bird supports long-term survival through the ice ages. BMC Evol Biol 2010, 10:35

88. Bernard R, Heiser M, Hochkirch A, Schmitt T: Genetic homogeneity of the Sedgling Nehalennia speciosa (Odonata: Coenagrionidae) indicates a single Würm glacial refugium and trans-Palaearctic postglacial expansion. J Zool Syst Evol Res 2011, 49:292-297.

89. Duriez O, Sachet JM, Menoni E, Miquel C, Taberlet P: Phylogeography of the capercaillie in Eurasia: what is the conservation status in the Pyrenees and Cantabrian mountains? Conserv Genet 2007, 8:513-526.

90. Bajc M, Čas M, Ballian D, Kunovac S, Zubić G, Grubešić M, Zhelev P, Paule L, Kraigher $\mathrm{H}$ : Genetic differentiation of the western capercaillie highlights the importance of south-eastern Europe for understanding the species phylogeography. PLoS One 2011, 6:e23602.

91. Drovetski SV, Zink RM, Rohwer S, Fadeev IV, Nesterov EV, Karagodin I, Koblik EA, Redkin YA: Complex biogeographic history of a Holarctic passerine. Proc R SOC B 2004, 271:545-551.

92. Drovetski SV, Zink RM, Ericson PGP, Fadeev IV: A multilocus study of pine grosbeak phylogeography supports the pattern of greater intercontinental divergence in Holarctic boreal forest birds than in birds inhabiting other high-latitude habitats. J Biogeogr 2010, 37:696-706.

93. Huck S, Büdel B, Kadereit JW, Printzen C: Range-wide phylogeography of the Europeam temperate montane herbaceous plant Meum athamanticum Jacq.: evidence for periglacial persistence. J Biogeogr 2009, 36:1588-1599.

94. Huck S, Büdel B, Schmitt T: Ice-age isolation, postglacial hybridization and recent population bottlenecks shape the genetic structure of Meum athamanticum in Central Europe. Flora 2012, 207:399-407.

95. Avise JC: Phylogenetic units and currencies above and below the species level. In Phylogeny and Conservation. Edited by Purvis A, Gittleman JL, Brooks T. New York: Cambridge University Press: 2005:76-101.

96. Szymura JM, Uzzell T, Spolsky C: Mitochondrial DNA variation in the hybridizing fire-bellied toads, Bombina bombina and B. variegata. Mol Ecol 2000, 9:891-899.

97. Canestrelli D, Cimmaruta R, Costantini V, Nascetti G: Genetic diversity and phylogeography of the Apennine yellowbellied toad Bombina pachypus, with implications for conservation. Mol Ecol 2006, 15:3741-3754.

98. Vörös J, Alcobendas M, Martínez-Solano I, García-París M: Evolution of Bombina bombina and Bombina variegata (Anura: Discoglossidae) in the Carpathian Basin: A history of repeated mt-DNA introgression across species. Mol Phylogenet Evol 2006, 38:705-718.

99. Hofman S, Spolsky C, Uzzel T, Cogalniceanu D, Babik W, Szymura JM Phylogeography of the fire-bellied toads Bombina: independent Pleistocene histories inferred from mitochondrial genomes. Mol Ecol 2007, 16:2301-2316.

100. Fink S, Excoffier L, Heckel G: Mitochondrial gene diversity in the common vole Microtus arvalis shaped by historical divergence and local adaptations. Mol Ecol 2004, 13:3501-3514.
101. Nadachowski A: Late Quaternary rodents of Poland with special reference to morphotype dentation analysis of voles. Warszawa: Panstwowe Wydawnictwo Naukowe; 1982.

102. Magri D, Vendramin GG, Comps B, Dupanloup I, Geburek T, Gomory D, Latalowa M, Litt T, Paule L, Roure JM, Tantau I, van der Knaap WO, Petit RJ, de Beaulieu JL: A new scenario for the Quaternary history of European beech populations: palaeobotanical evidence and genetic consequences. New Phytol 2006, 171:199-221.

103. Magri D: Patterns of post-glacial spread and the extent of glacial refugia of European beech (Fagus sylvatica). J Biogeogr 2008, 35:450-463.

104. Litynska-Zajac M: Anthracological analysis. In Complex of Upper Palaeolithic sites near, Moravany, Western Slovakia. Edited by Hromada J, Kozlowski J. Krakow: Jagellonian University Press; 1995:74-79.

105. Willis KJ, Sümegi $P$, Braun M, Toth A: The late Quaternary environmental history of Bátorliget, NE Hungary. Palaeogeogr Palaeoclimate Palaeoecol 1995, 118:25-47.

106. Willis KJ, Rudner E, Sümegi P: The full-glacial forests of Central and southeastern Europe. Quat Res 2000, 53:203-213.

107. Rudner ZE, Sümegi P: Recurring Taiga forest-steppe habitats in the Carpathian Basin in the Upper Weichselian. Quat Internat 2001, 76/ 77:177-189.

108. Sümegi $P$, Rudner ZE: In situ charcoal fragments as remains of natural wild fires in the upper Würm of the Carpathian Basin. Quat Internat 2001, 76/77:165-176.

109. Willis KJ, Niklas KJ: The role of Quaternary enviromental change in plant macroevolution: the exception or the rule. Phil Trans R Soc Lond B 2004, 359:159-172.

110. Willis KJ, van Andel TH: Trees or no trees? The environments of central and eastern Europe during the Last Glaciation. Quat Sci Rev 2004, 23:2369-2387.

111. Feurdean A, Wohlfarth B, Björkman L, Tantau I, Bennike O, Willis KJ, Farcas S, Robertsson AM: The influence of refugial population on Lateglacial and early Holocene vegetational changes in Romania. Rev Palaeobot Palynol 2007, 145:305-320.

112. Normand S, Ricklefs RE, Skov F, Bladt J, Tackenberg O, Svenning JC: Postglacial migration supplements climate in determining plant species ranges in Europe. Proc $R$ SOC B 2011, 278:3644-3653.

113. Petit RJ, Aguinagalde I, de Beaulieu J-L, Bittkau C, Brewer S, Cheddadi R, Ennos R, Fineschi S, Grivet D, Lascoux M, Mohnty A, Müller-Starck G, Demesure-Musch B, Palmé A, Pedro Martin J, Rendell S, Vendramin GG: Glacial refugia: hotspots but not melting pots of genetic diversity. Science 2003, 300:1563-1565.

114. Hampe A, Petit RJ: Conserving biodiversity under climate change: the rear edge matters. Ecol Lett 2005, 8:461-467.

115. Stewart JR: The evolutionary consequence of the individualistic response to climate change. J Evol Biol 2009, 22:2363-2375.

doi:10.1186/1742-9994-9-22

Cite this article as: Schmitt and Varga: Extra-Mediterranean refugia: The rule and not the exception?. Frontiers in Zoology 2012 9:22.

\section{Submit your next manuscript to BioMed Central and take full advantage of:}

- Convenient online submission

- Thorough peer review

- No space constraints or color figure charges

- Immediate publication on acceptance

- Inclusion in PubMed, CAS, Scopus and Google Scholar

- Research which is freely available for redistribution 